\title{
English Teachers' Responses to the New Indonesian Education Paradigm: A Case Study of Batu Layar English Teachers' Consultative Group
}

\author{
Yuni Budi Lestari ${ }^{1}$, Kamaludin Yusra ${ }^{2}$, Arifuddin ${ }^{3}$, Ni Wayan Mira Susanti ${ }^{4}$,

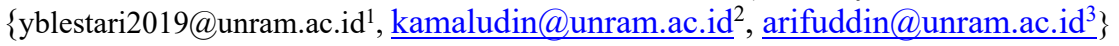 \\ School of English Education, Faculty of Teachers Training and Education \\ The University of Mataram, Mataram, Indonesia ${ }^{1,2,3}$
}

\begin{abstract}
Under the new Indonesian education paradigm, "guru penggerak" (mover teachers) and "merdeka belajar" (freedom in learning), teachers, including English teachers, in Indonesia are given room to use teaching materials and strategies appropriate to students' condition and need. However, it is not clear how this paradigm is responded by English teachers given the lack of learning resources. This paper examines English teachers' responses to the new Indonesian education paradigm based on data obtained from a case study of Batu Layar English Teachers' Consultative Group (MGMP) in West Lombok involving twenty (20) teachers purposively selected as the sample of the study. The data were collected through observing teachers' activities in the MGMP meetings, interviewing them on how they respond to the new education paradigm and collecting teaching and learning related documents. The results show that students and pedagogical factors influence the teachers to positively and negatively respond to the new education paradigm.
\end{abstract}

Keywords: new education paradigm, mover teachers, freedom in learning, teachers' responses.

\section{Introduction}

While other ASEAN countries enthusiatically respond to the importance of the English language as a global language by enacting education policies that require teaching English at early or primary school level, Indonesian education policy recommends teaching English from grade 7 of Junior High School. The policy also prescribes that the ultimate goal of learning English includes not only the acquisition of English language knowledge and skills but also the formation of character and mental attitudes of professionals oriented towards the ability to adapt to global developments.

Most recently, the Minister of Education, Nadiem Makarim, initiated a new paradigm of Indonesian education, 'mover teacher' (guru penggerak) and 'freedom in learning' (merdeka 
belajar). Under this paradigm teachers are given the flexibility to use an English teaching approach that could facilitate students' learning according to the students' need, interest dan socio-cultural background.

The new Indonesian education paradigm is a shift from the traditional paradigm characharacterized by the teacher being seen as a 'transfer of knowledge' which, as Brown (2001) point out, tends to limit the scope of student learning and inhibits students from thinking creatively and critically. In contrast to this traditional pardigm, the notion of 'mover teacher and freedom in learning' assign teacher take the role as a facilitator while giving students freedom to seek learning resources and opt to use learning strategies suitable for their interests and needs.

Although this new Indonesian eucation paradigm is seen to be in accordance with national needs, and priorities, it is still unclear how this new paradigm will be applied by teachers in Indonesia with different situations, conditions and cultural backgrounds. It is, therefore necessary to conduct research on teacher responses to the new Indonesian education paradigm of 'mover teacher' and 'freedom in learning'. For reasons of time and space, this study focuses on investigating the way English teachers in Batu Layar English Teachers' Consultaive Group respond to the new Indonesian education paradigm.

\section{Teacher Agency in ELT Practices}

In language planning and policy studies, the concept of teacher agency has been defined as an effective strategy used by a policy actor to face challenges and bring change on purpose (Ali \& Hamid, 2018). The level of practice of an agency may vary from context to context depending on where the agency operates. At the macro level, agency is in the form of policies, guidelines and training modules, while at the micro level teachers exercise their agency by responding to policies at the macro level according to the situation in which the works. However, as stated by Zao and Baldauf (2012), the concept of agency must shift from agents at the macro level to agents at micro level. Zao and Baldauf further point out that the agents at macro level are people who have power to impose policy on to agents at the micro level who can bring changes at the micro level by responding to macro level policy by initiating and implementing the interventions needed at the micro level.

However, not all strategic efforts made can be said to be agency. As mentioned by Emirbayer and Miesche (1998), agency is routinely carried out over a long period of time. Meanwhile, Biesta and Tedder (2013) confirm that agency is carried out in a context in which individuals acquire their agency roles. This role taking is motivational in the sense that the individual has an interest or dedication to influence change at the micro level. Priestley, Biesta, and Robinson (2013) have claimed that actions are taken as motivated by teachers' belief in their own self-efficacy to achieve performance standards. However, Zhao and Baldauf (2012) and Ali and Hamid (2018) have shown that English teachers exercise their agency even when they do not have the necessary capacity and when their actions are motivated by social and professional responsibility towards students. Ollerhead and Burn (2013) also argue that the practice of agency by teachers depends on the socio-cultural and professional backgrounds of English teachers and the culture of the institutions they are in. For the agency to take effect, English teachers must have a strong belief in themselves that they have personal capacity and previous training and experience in coping with the situation at 
hand. When teachers believe they have the capacity necessary to carry out the agent role, they will vigorously seek out options in their repertoire for solving problems.

However, Canagarajah (2002) emphasizes the importance of support from the environmental community for teachers to create their agency. In relation to this Ollerhead and Burns (2015) remind that teacher agency in schools will also depend on the availability of teaching materials, student skills, and school conditions.

There have been a number of studies on English teacher agencies at the micro level that are relevant to this current study. $\mathrm{Ng}$ and Boucher-Yip, 2017, for example, review how English teachers in various contexts in ASIA are committed to maintaining, implementing and changing English language learning policies. Another study (see Pessoa \& Glasgow, 2015; Vijay, 2014) has invesigated how an English teacher applies agency through critical pedagogy by ignoring government policies and by paying full attention to student aspirations as well as student cultural norms and practices. This is relevant because it discusses the response of English teachers, especially in ASIA, to education policy. Slightly different from these studies, the current research will examine how English teachers exercise their agency in responding to the new paradigm of Indonesian education that has not been implemented as an educational policy.

\section{Methodology}

\subsection{Research Approach}

The research question of the study is how English teachers respond to the new Indonesian education paradigm; accordingly, a qualiatitative approach is used as the method of the study. Aqualitative approach is suitable for this study as it canprovide a detailed description of how each English teacher responds to the new paradigm of Indonesian education. As Merriam (1998, p. 19) argues, for a richer description of "one unit" and "system-bound" such as English learning in schools, a researcher needs to use a qualitative approach to data collection and analysis and in this way one is it is possible to explain the case more objectively to the views of the research subjects and not to the researcher. In this perspective, this study is qualitative because, following Kirk and Miller (1986), this study seeks to understand the world through the interpretation of information obtained from research subjects or informants.

Since this study intends to explain how local teachers respond to national changes arriving in their immediate environment, the notion of 'locality' attached to them needs to be scrutinized. Therefore, a case study is applied to this research. As Miles and Huberman (1994) emphasize, a case study investigates what processes occur in a particular event and what relationships exist between processes and events in a specific and limited location. In this case this study focuses on the description and analysis of the responses of teachers who are members of Batu Layar English Teachers Consultative Group (MGMP). Towards a new Indonesian education paradigm 'Mover Teacher and Freedom in learrning'. The focus of the description and analysis is on the material aspects and methods of learning English in the classroom. 


\subsection{Research Sample and Population}

The population of the study is all teachers who are the members of English Teacher Consultative Group in West Lombok. The sample of the study comprises of 20 teachers from 10 different schools who are the members of Batu Layar Teacher Consultative Group. The sampel was taken purposively as the teachers came from schools in a remote area who would provide much needed information regarding the issue of education access in remote area.

\subsection{Data Collection}

Data collection techniques used in this research are observation, interview and documentation. Observation is used to observe the activities carried out by the teacher in the MGMP meeting. Semi- structured interview was used to interview English teachers. Documentation was also used to obtain supporting data from interviews and observations. Therefore documents such as lesson plans, learning materials, instructional media and syllabus are needed to support the data obtained from observations and interviews.

\subsection{Data Analysis}

Data analysis begins by examining all data obtained from documentation, interviews, observations that have been written in the field notes. After reading, studying and analysing the data from documentation, interviews and observations, the next step is sumarizing the field notes by sorting out the main things related to the research question. The notes are then arranged systematically to provide a clearer and sharper picture. The next step is seeing all the overall picture of the research result so that the researchers can draw conclusions and verify the data by examining and reexamining the intepretation of the data so that they become meaningful.

\section{Findings and Discussion}

Research on teacher responses at the micro level to educational policies at the macro level in the ASIA context has been conducted by researchers with the expertise of Language, Planning and Policy and Teacher Agency (for example, Pan \& Hamid, 2017; Ng \& Bouche Yip, 2017; Glassgow, 2017 ). Based on the results of this study, education policies received various responses from schools, especially teachers as actors or implementers of educational policies. Below is described how teachers respond to the new paradigm of education in Indonesia, "mover teachers and freedom in learning" which is the latest government policy in the field of education that is expected to be implemented nationally.

\subsection{English Teachers' Responses to the New Paradigm of 'Mover Teacher and Freedom in Learning'}

In the new Indonesian education paradigm, teaching and learning activities are no longer teacher-centered but student-centered. With this student-centered learning, the teacher is no longer seen as a transfer of knowledge but as a learning facilitator, students' active learning, authentic learning materials and activities, the use of open-ended question types, learning that 
is in accordance with the students' interests and needs (Brown, 2001; Richard, 2012). Based on this student-centered learning, in the framework of the new paradigm, teaching and learning practices are recommended to use the Communicative Language Teaching approach, the Technological Pedagogical Content Knowledge (TPACK) learning model, the ProblemBased Learning and Project-Based Learning methods with scientific learning procedures or $\mathbf{5 M}$ as already prescribed in the 2013 curriculum. The implementation of this macro education policy depends on the professional and pedagogical readiness of teachers as well as the conditions of the school and the students' economic, social and cultural backgrounds. As a result, this policy will lead to different responses between teachers in one area and those in another area. As the role of teachers is very important in education, it is necessary to know their responses to education at the macro level.

Following Ali and Hamid (2018), teachers' strategies in responding to educational policies, especially in English language teaching, can be divided into three, namely, dedication, accommodation and resistance. At the macro level, education policy actors expect teachers as actors at the micro level to adopt the latest curriculum including aspects suggested in the new paradigm. This adoption process is known as dedication. Conversely, if the teacher does not want to adopt the latest curriculum along with the aspects mentioned in the new paradigm, the teacher's response is called resistance. Meanwhile accommodation is when the teacher bridges the gaps between the policies recommended at the macro level and the real conditions of their students and the school where they do teaching practice.

Using Ali and Hamid's (2018) framework, researchers found teacher responses to the new paradigm of Indonesian education as presented in table 4.2. below.

Table 4.1 Teacher responses to the new paradigm of education

\begin{tabular}{llll}
\hline No & Teachers' Response & Frequency & $\%$ \\
\hline 1. & Dedication & 20 & 18 \\
2. & Acomodation & 60 & 52 \\
3. & Resistance & 35 & 30 \\
& Total & 115 & 100 \\
\hline
\end{tabular}

As can be seen in table 4.1 above, teachers used the three kinds of strategies as mentioned above in responding to the new paradigm of education, namely dedication, accommodation and resistance with accommodation having the percentage of $60 \%$, much higher than that of resistance (35\%) and dedication. (20\%).

Based on the findings, dedication can be seen when teachers used TPACK by integrating technology in their learning environment. An example for this is the use of animated videos by the teacher to explain a concept, to provide a language model, and also as an elicitation question to find out the students' background knowledge of the topic to be studied. Another example of dedication found in this study is when the teacher used the $5 M$ scientific procedure in teaching which includes Observing, Questioning, Associating, Experimenting, and communicating. By using this scientific procedure, the teacher provided assignments or learning activities that are project-based learning and also problem-based learning.

Meanwhile, the teacher's response as accommodation can be seen when the teacher used scientific procedures in their learning practice and provided assignments and learning 
activities to students that are Problem Solving- Based and Project-Based Learning but do not integrate ICT in their teaching. The reason for not using ICT was related to the limited learning facilities such as a tv monitor screen in the schools. However, the teacher accommodated it by providing or showing pictures to students to introduce or to explain the concept or meaning in addition to giving elicitation questions to find out students' background knowledge of the topic to be studied. The teacher accommodation strategy can help students contextualize learning based on the conditions and needs of their students (Canagarajah, 2012).

Meanwhile, resistance strategy was chosen by teachers in general because educational policies at the macro level were deemed impossible to be implemented because they were not suitable for school conditions and the level of student competence faced by teachers (Ollerhead and Burns, 2015). In this study, teachers' resistance to the new education paradigm was shown by the use of translation and memorization methods, which are not recommended by the new national curriculum. In addition, the teachers teach grammar and vocabulary with deductive and explicit explanations that do not provide opportunities for students to experiment, finding formulas and concepts of grammar and vocabulary. Teacher resistance is also shown by the teachers' using drilling technique. Thus, teacher-centered learning is still visible. Based on the results of interviews with teachers, this resistance strategy was carried out by teachers due to srudents' low motivation and English competency. However, based on the results of the interviews, it was found that this resistance was also due to both lack of English language skills and the teacher's pedagogical skills. As the teachers reported, this is because they are busy with administrative activities and teaching at other schools to meet the minimum standard of teaching hours. Even though teachers used resistance strategies against education policies at the macro level, it does not mean that teachers are resistant to developing student competencies. On the other hand, the teachers' using resistance strategy was for the continuity of the teaching and learning practices within limited learning resources, low level of students' and teachers' English competencies.

\section{Conclusion}

A new education paradigm in Indonesia has been proposed to pursue a national agenda. While the government recommends the implementation of the education paradigm nationwide, teachers reponded it differently. Three different agentic strategies were deployed by the teachers in responding the education pardigm: dedication, accomodation and resistance. Accomodation strategies was mostly used by the teachers in bridging the gap between the local conditions and the national expectations. The study has shown teachers' decision to use the responsive strategies is dependent upon the circumstances, responsibilities, and resources available within their contexts.

\section{References}


[1] Ali, N.L., \& Hamid, M.O. (2018). English-medium instruction and agency in higher Education: A case study. In P.C.C. Lian, C.

teacher Leech \& C. Williams (Eds.), Un(intended) language planning in a globalising world: Multiple levels of players at work (pp. 234-250). Berlin: De Gruyter Open. doi:10.1515/9783110518269-013.

[2] Biesta, G. J. J., \& Teddler, M. (2006).How is agency possible?: Towards an ecological understanding of agency as achievement.Working Paper 5.Retrived from http://hdl.handle.net/10993/13718.

[3] Canagarajah, A.S. (2002). Globalisation, methods, and practice in periphery classroom. In D. Block \& D. Cameron (Eds.), Globalisation and language teaching (pp. 134-150). London: Routledge.

[4] Glasgow, B.P. (2017). Policy agency and the (non) native teacher: "English classes in English in Japan's high school. In P.C.L. Ng \& E.F. Boucher-Yip (Eds.), Teacher agency and policy response in English language teaching (pp. 58-73).New York: Routledge

[5] Ng, P. C. L., \& Boucher-Yip, E. F. (2017).Introduction. In P.C.L. Ng \& E.F. Boucher-Yip (Eds.), Teacher agency and policy response in English language teaching (pp.1-9)New York, Routledge.

[6] Phan, T.T.H., \& Hamid, M.O. (2017). Learner autonomy in foreign language policies in Vietnamese universities: An exploration of teacher agency from a sociocultural perspective. Current Issues in Language Planning, $\quad 18(1), \quad 38-56$. doi:10.1080/14664208.2016.120123.

[7] Vijay, G. (2014). Constraints of teaching English in engineering colleges. Language in India, 14 (12), 687-693.

[8] Zhao, S., \& Baldauf, R. B. (2012).Individual agency in language planning.Language Problems and Language Planning, 36(1), 1-24. 